\title{
Nutritional resuscitation of children with disordered eating
}

\author{
Lyza Norton*, Laura Owens \\ From 2015 ANZAED Conference: Riding the Waves to Recovery \\ Surfers Paradise, Australia. 21-22 August 2015
}

Medically compromised patients with disordered eating are admitted to the childrens ward of the Gold Coast University Hospital following a treatment protocol, including immediate insertion of nasogastic tube and commencement of enteral feeding, which is independent of admitting diagnosis, including anorexia nervosa, eating disorder not otherwise specified, anxiety and mood disorders.

Data has been collected and analysed over a 12 month period to include the diagnosis, BMI Z-scores corresponding to severity of malnutrition on admission, weight gained over admission, length of stay and follow up plans including readmission rates.

This presentation highlights the importance clear admission criteria and immediate nutritional resuscitation for the spectrum of disordered eating diagnoses and its effect on rectifying malnutrition, reducing readmission rates and improving the health outcomes for this population.

Published: 23 November 2015

doi:10.1186/2050-2974-3-S1-065

Cite this article as: Norton and Owens: Nutritional resuscitation of

children with disordered eating. Journal of Eating Disorders 2015

3(Suppl 1):065

* Correspondence: lyzanorton@gmail.com

Gold Coast University Hospital, Queensland, Australia

Submit your next manuscript to BioMed Central and take full advantage of:

- Convenient online submission

- Thorough peer review

- No space constraints or color figure charges

- Immediate publication on acceptance

- Inclusion in PubMed, CAS, Scopus and Google Scholar

- Research which is freely available for redistribution

C 2015 Norton and Owens. This is an Open Access article distributed under the terms of the Creative Commons Attribution License (http://creativecommons.org/licenses/by/4.0), which permits unrestricted use, distribution, and reproduction in any medium, provided the original work is properly cited. The Creative Commons Public Domain Dedication waiver (http://creativecommons.org/ publicdomain/zero/1.0/) applies to the data made available in this article, unless otherwise stated. 